\title{
TSC2 Gene
}

National Cancer Institute

\section{Source}

National Cancer Institute. TSC2 Gene. NCI Thesaurus. Code C18260.

This gene plays a role in signal transduction and cell cycle control. It is involved in cell adhesion, differentiation, growth and migration. 